\title{
Symptomatological aspects associated with fungal incidence and fumonisin levels in corn kernels
}

\author{
Fabrício E. Lanza ${ }^{1}$ - Laércio Zambolim ${ }^{2}$ Rodrigo V. Costa ${ }^{1}$. José E. F. Figueiredo ${ }^{1}$. \\ Dagma D. Silva ${ }^{1} \cdot$ Valéria A. V. Queiroz $^{1} \cdot$ Elaine A. Guimarães ${ }^{1} \cdot$ Luciano V. Cota $^{1}$
}

Received: 4 April 2016 / Accepted: 6 March 2017 /Published online: 15 March 2017

(C) Sociedade Brasileira de Fitopatologia 2017

\begin{abstract}
Toxigenic fungi that infect corn grains are among the major problems in Brazil as they are associated with toxicological implications for both humans and animals. Mechanical-physical methods have been used to separate contaminated grains in lots of corn kernels based on the symptoms caused by fungi. The objective of this study was to assess whether the presence or the type of symptoms were associated with fungal incidence and total fumonisin levels in corn kernel samples from the field. Kernels of two hybrids were separated visually into three groups: 1) asymptomatic or symptomatic exhibiting 2) kernel rot or 3) kernel streak symptoms. A high frequency of Fusarium spp. was observed in asymptomatic $(69.5 \%)$ and kernel rot $(69.9 \%)$. Stenocarpella sp. and Penicillium sp. were found in kernel $\operatorname{rot}(16.0 \%)$ and kernel streak (44.1\%), respectively. High fumonisin levels (7.24 $\mu \mathrm{g} \cdot \mathrm{g}^{1}{ }^{1}$ ), above the maximum tolerated limit, were detected only in kernel rot. No association between fumonisin levels and the frequency of Fusarium spp. in kernels was found.
\end{abstract}

Keywords Zea mays · Corn grain symptomatology · Fungal incidence $\cdot$ Mycotoxins

Brazil is the third largest producer of corn with 84 million tons of corn grain produced in the 2014/15 growing season

Section Editor: Paul D. Esker

Luciano V. Cota

luciano.cota@embrapa.br

1 Embrapa Milho e Sorgo, Rod MG 424, Km 65, Cx. Postal 151, Sete Lagoas, MG 35701-970, Brazil

2 Departamento de Fitopatologia, Universidade Federal de Viçosa, Viçosa, MG 36570-900, Brazil
(CONAB 2016). However, the sanitary quality of grains creates barriers to export and poses serious risks to human health (Koffi-Nevry et al. 2013). In recent years, there is a growing public and private demand for high quality and safe grains for food and feed. As a result, regulatory guidelines became more severe for the presence of contaminants in grains for both the domestic consumption and export, particularly for mycotoxins not only in Brazil but also worldwide (ANVISA 2017; EURL 2006; FDA 2001).

In Brazil, corn is grown all over the country and under a wide range of climatic conditions, and is a host for a large number of pathogens that can cause reductions in grain quality, some of which can also produce toxins dangerous to humans and animals (Oliveira et al. 2004). Fumonisins are the most important group of mycotoxins found in Brazilian corn and are known to be harmful to animals and to cause certain types of cancer in humans (Munkvold and Desjardins 1997; Gelderblom et al. 1988; Jackson and Jablonski 2004). Although fumonisins are produced by several Fusarium species, Fusarium verticillioides is the most commonly fungi infecting corn kernels and causing ear and kernel rot (Munkvold and Desjardins 1997; Lanza et al. 2014).

Considering the importance of fumonisins to human health, government and food processing industry of many countries have implemented programs to monitor mycotoxin levels in corn grain and products. In Brazil, the food industry adopted a $6 \%$ tolerance for the presence of kernel rot in commercial lots of corn grain (Pinto et al. 2007). In addition, the National Agency for Sanitary Surveillance (ANVISA), have established a maximum tolerance limit (MTL) of $5 \mu \mathrm{g} . \mathrm{g}^{1}{ }^{1}$ of total fumonisins $\left(\mathrm{B}_{1}+\mathrm{B}_{2}\right)$ for corn grain (ANVISA 2017).

Considering the new guidelines imposed by agribusinesses and government agencies in Brazil to improve the quality of corn grain, the development of new management strategies is 
necessary to reduce fumonisin contamination in grains (Munkvold and Desjardins 1997; Shetty and Bhat 1999; Pearson and Wicklow 2006). The use of more resistant hybrids is the principal strategy used by Brazilian farmers for controlling corn diseases (Costa et al. 2012). Furthermore, post-harvest strategies, such as mechanical separation of symptomatic grains or separation of fungal-infected corn kernels by density difference are important to improve the sanitary quality of grain (Shetty and Bhat 1999; Pearson and Wicklow 2006). However, little is known about the relationship between fumonisin levels and disease symptoms in corn grain. Kernel rot symptoms such as damaged kernels or streaked grains are typical of fungal infections that reduce grain quality (Pearson and Wicklow 2006; Pinto et al. 2007). Thus, the goal of this study was to investigate the association between symptoms induced by fungal pathogens in corn kernels with the fungal incidence and total fumonisin levels.

The experiment was performed at the Embrapa Maize and Sorghum Research Center, Sete Lagoas, Minas Gerais, Brazil. Two commercial hybrids, BRS1010 (Embrapa) and 2B710 (Dow AgroSciences), both rated as moderately resistant to fungal diseases, were grown during the 2011/12 crop season. The planting date was $11 / 11 / 2011$ and the experimental design was a randomized complete block design in a factorial arrangement ( 2 genotypes $\times 3$ symptoms), with three replications. Each plot consisted of four rows measuring five meters in length, with $0.8 \mathrm{~m}$ between rows and an average of five plants per meter. A one-meter distance between the sides and the ends of each plot was kept. Crop fertilization consisted of the application of $350 \mathrm{~kg} \cdot \mathrm{ha}^{-1}$ of NPK fertilizer (8-28-16) $+\mathrm{Zn}$ at planting. Two applications of urea $\left(150 \mathrm{~kg} \cdot \mathrm{ha}^{-1}\right)$ were made at 30 and 45 days after planting (DAP), respectively.

Grains without any apparent symptoms were scored as asymptomatic (Fig. 1a), while those showing at least $25 \%$ of the surface with discoloration, whose hue varied from light brown to purple or bright red to red-intense, were scored as kernel rot (Fig. 1b) (Pinto 2005; Trento et al. 2002; Pinto et al. 2007). The kernel streak (starburst symptoms) symptom type was assigned to grains showing unidirectional white spots, also known as streaks, on a portion of the grain surface (Fig. 1c).

By the time of crop maturity (150DAP), all ears from the two center rows of each plot were harvested and threshed, and the total grain from each plot was mixed thoroughly to obtain a random distribution of the kernels. A grain sample of $500 \mathrm{~g}$ from each plot was taken to determine the frequency of symptom type and the amount grain fumonisins levels. Grain from each sample was separated into three classes based on the presence and type of symptos: asymptomatic grains, kernel rot, and kernel streak (Fig. 1).

The incidence of fungi associated with asymptomatic grain, kernel rot and kernel streak was determined using a blotter test with freezing (Pinto et al. 2007). Two hundred kernels previously desinfeted with $2 \%$ sodium hypochlorite for five minutes were placed into germination plastic boxes (eight replicates, with 25 kernels in each box) containing three filter paper layers moistened with 5\% water-agar. The boxes were incubated at $25^{\circ} \mathrm{C}$ and $12 \mathrm{~h}$ photoperiod for 10 days. Kernels were then examined individually using a stereomicroscope to determine fungal incidence.

For the quantification of total fumonisins in corn grain, the water content of grain samples was reduced in an oven at $65^{\circ} \mathrm{C}$ under forced ventilation for $72 \mathrm{~h}$. After cooling, grain samples were ground and sieved to mesh size 20. Total fumonisins were extracted in methanol:water (80:20) and purified by FumoniTest ${ }^{\circledR}$ (VICAM Inc.) immunoaffinity column, and total fumonisin levels were determined by fluorometer according to the manufacturer's instructions (VICAM, 2011). A reference sample of fumonisins (TR-F100, Trilogy Analytical Laboratory, Inc.) quantified by High-Performance Liquid Chromatography (HPLC) $\left(4.1 \mu \mathrm{g} \cdot \mathrm{g}^{-1} \pm 0.5\right)$ was used to assure the accuracy test of the immunoaffinity column method.

The variables fungal incidence and concentration of fumonisins were subjected to analysis of variance by SISVAR statistical program (Ferreira 2011). Data were arcsinetransformed prior to analyses and treatment means were compared by the Tukey test at $5 \%$ probability.
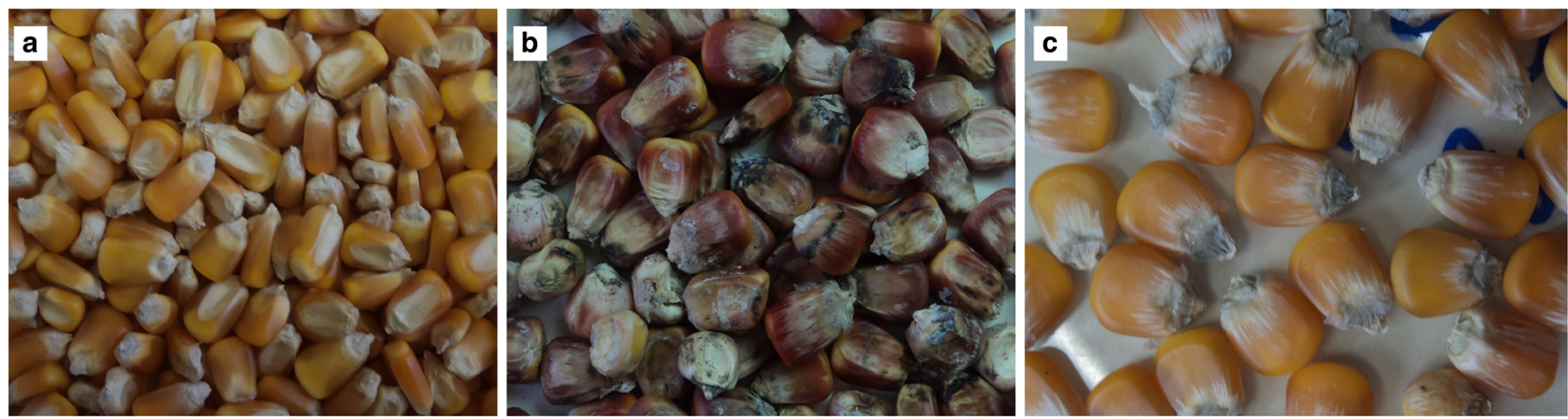

Fig. 1 Symptoms of fungal infection in corn kernels. a asymptomatic grain; $\mathbf{b}$ kernel rot; $\mathbf{c}$ kernel streak 
Table 1 Incidence of Fusarium sp., Penicillium sp. and Stenocarpella $s p$. in corn grain types classified according to the presence and type of symptom

\begin{tabular}{llll}
\hline Grain type & \multicolumn{3}{l}{ Incidence $(\%)^{*}$} \\
\cline { 2 - 4 } & Fusarium $\mathrm{sp}$. & Penicillium $\mathrm{sp}$. & Stenocarpella sp. \\
\hline Asymptomatic & $69.5 \mathrm{bC}$ & $29.0 \mathrm{aB}$ & $1.0 \mathrm{aA}$ \\
Kernel streak & $60.8 \mathrm{aC}$ & $44.1 \mathrm{bB}$ & $1.6 \mathrm{aA}$ \\
Kernel rot & $69.9 \mathrm{bC}$ & $22.5 \mathrm{aB}$ & $16.0 \mathrm{bA}$ \\
\hline
\end{tabular}

* Means followed by the same letter, lowercase (vertically) and uppercase (horizontally), do not differ by Tukey test at $5 \%$ probability

Four fungal genera were associated with corn kernels were identified: Fusarium, Penicillium, Stenocarpella, and Aspergillus. For fungal incidence, significant effects were found for genotype and grain type, for Fusarium $(P=0.015$ and 0.001 respectively), Penicillium ( $P=0.001$ and 0.001 respectively), and Stenocarpella ( $P=0.022$ and 0.001 respectively), but not for Aspergillus ( $P=0.43$ and 0.65 respectively). The interaction effect was not significant for any of the fungi $(P>0.55)$.

Genotype 2B710 showed higher incidence of Fusarium sp. (75\%) compared to the BRS1010 genotype (61\%) $(P=0.001)$. Conversely, the incidence of Penicillium sp. and Stenocarpella sp. were higher in BRS1010 (42.3\% and $8.7 \%$, respectively) than in $2 \mathrm{~B} 710(21.4 \%$ and $3.8 \%$, respectively) $(P<0.001)$. With regards to grain type, the incidence of Fusarium sp. in asymptomatic grains and kernel rot was higher than in kernel streak grains (Table 1). For Penicillium sp. a higher incidence was observed in kernel streak, while for Stenocarpella sp. higher incidences were observed in kernel rot (Table 1). For Aspergillus sp., the mean incidence across the genotype and grain type was $0.71 \%$.
Analysis of variance of total fumonisins showed a significant effect only for grain type $(P=0.001)$. The highest total fumonisin level was detected in kernel rot with the average value of $7.24 \mu \mathrm{g} . \mathrm{g}^{-1}$ (Fig. 2). There was no significant difference between the means of total fumonisins for asymptomatic grains and kernel streak, which averaged $1.39 \mu \mathrm{g} . \mathrm{g}^{-1}$ and $1.08 \mu \mathrm{g} . \mathrm{g}^{-1}$, respectively.

In our study, the highest incidences of Stenocarpella sp. and Fusarium sp. were found associated with kernel rot, corroborating previous reports (Pinto 2005, Pinto et al. 2007). The fact that kernel streak was associated with the incidence of Penicillium sp. contradicts Duncan and Howard (2010) who reported that kernel streak was mainly associated Fusarium sp., most often $F$. verticillioides. Those authors also reported that kernel streak originates from the insertion point of the style attachment to the kernel in the hilar region. We found that the development of the streaks initiated at the kernel insertion point into the corn cob (hilum) and progressed to the upper part of the kernel (Fig. 1c). This may be a key for differentiating symptoms by Penicillium sp. and Fusarium sp.

Aspergillus spp. and Penicillium spp. were identified both in symptomatic grain and kernel rot, but the incidence of Penicillium was higher in kernel streak. The incidence of those pathogens in corn kernels is worrisome because of their toxigenic potential, which are associated with some types of cancer in humans and animals (Machinski et al. 2001). Although in Brazil high levels of aflatoxins and incidence of Aspergillus spp. have been reported (Machinski et al. 2001; Ramos et al. 2010), we found a lower incidence of this fungal genus compared to previous reports. The mycotoxins aflatoxins and ochratoxins, which are mainly produced by Aspergillus and Penicillium, respectively, were not quantified in this study.
Fig. 2 Total fumonisin levels in corn grain samples with different types of symptoms: kernel streak, asymptomatic grain and kernel rot. Means followed by the same letter do not differ by Tukey test at $5 \%$ probability

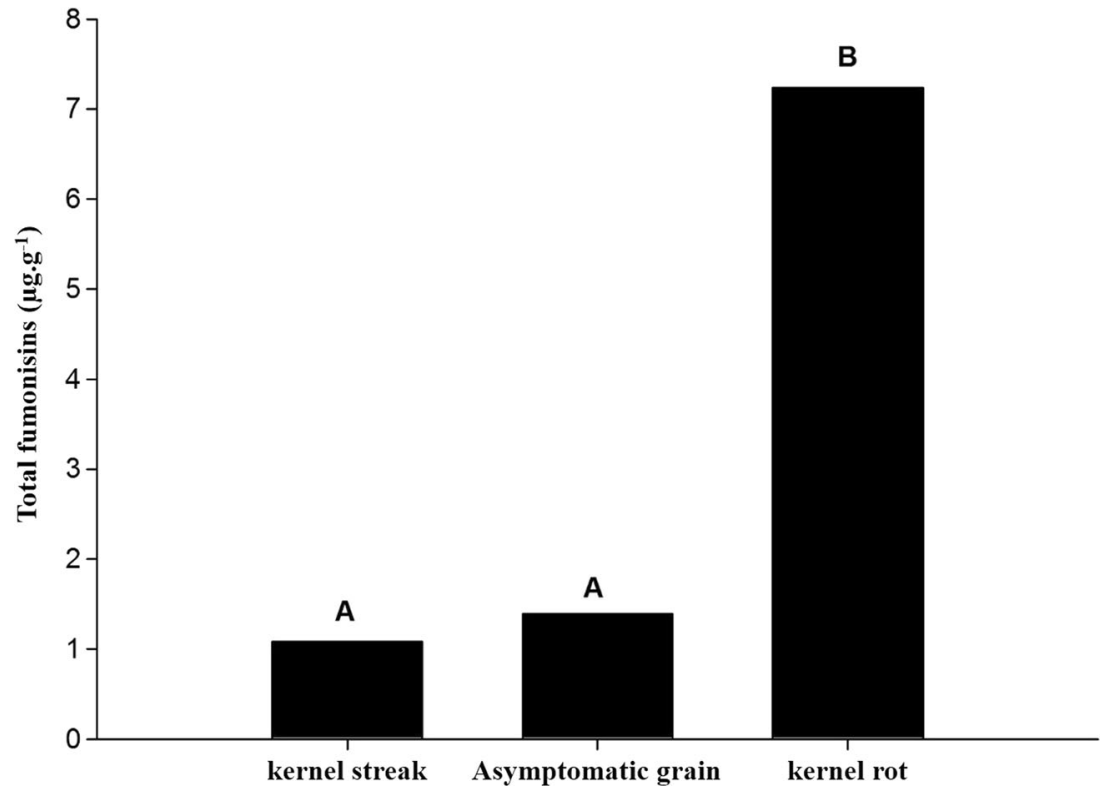


Literature reports on the association between symptoms on grains and fungal incidence are limited. The incidence of Fusarium sp. did not differ between asymptomatic kernels and kernel rot, and it was lower in kernel streak, corroborating previous reports (Munkvold and Desjardins 1997). Nonetheless, we found low levels of fumonisins in samples of asymptomatic grain, while Munkvold and Desjardins (1997) suggested that asymptomatic grain infected with Fusarium sp. may contain high levels of fumonisin. The contrasting results may be due to differences in corn genotypes, pathogen variability or environmental conditions (Picot et al. 2010).

For the two commercial hybrids tested in our study, the high incidence ( $>69 \%$ ) of Fusarium $\mathrm{sp}$. in both asymptomatic and kernel rot kernels suggests that this fungus is the main rotting agent of corn kernels. Regarding Stenocarpella sp., we found low incidence in asymptomatic kernels (1\%) and kernel streak (1.6\%), and higher incidence in kernel rot $(16 \%)$ (Table 1), which suggest its secondary role in kernel rot and ear rot for the conditions of our experiments. Further studies with a larger number of genotypes and different environmental conditions are needed to confirm this hypothesis.

Duncan and Howard (2010) reported that streaks in corn kernels were mainly associated with Fusarium infection. We found that streak symptoms were associated only with higher incidence of Penicillium sp. Futhermore, our results showed that higher fumonisin levels were not always associated high incidence of Fusarium sp., once the level of this toxin was low in asymptomatic grain and high in kernel rot, while the Fusarium sp. incidence did not differ between these two grain types. Also important was that high fumonisin level was detected only in kernel rot, while the fumonisin levels in asymptomatic grains and kernel streak was below to the Brazilian regulation of maximum tolerated limit of $5 \mu \mathrm{g} \cdot \mathrm{g}^{-1}$ (ANVISA 2017). Thus, under conditions conducive for fumonisins production, the Fusarium-infected asymptomatic or kernel streak symptom may contain fumonisins at levels of risk to human health (Munkvold and Desjardins 1997; Picot et al. 2010).

We confirmed that the highest frequencies of Fusarium sp., Penicillium sp., and Stenocarpella sp. were associated with kernel rot and asymptomatic grains, kernel streak, and kernel rot, respectively. Higher levels of fumonisins were found in rotted kernels and there was no association between fumonisins and the incidence of Fusarium sp. in the grain. Nevertheless, the assessment of symptoms on healthy grain may be useful for improving methods of mechanicalphysical separation as proposed previously (Shetty and Bhat 1999; Pearson and Wicklow 2006). To best or our knowledge, this is the first study on the association between symptoms on kernels and fungal incidence and fumonisins in Brazilian corn.
Acknowledgements Fabrício Eustáquio Lanza thanks CNPQ for his $\mathrm{PhD}$ and PostDoctoral scholarship. The authors thank the Embrapa Maize and Sorghum, CNPq and FAPEMIG for the financial, structural and technical support.

\section{References}

ANVISA (2017) Agência Nacional de Vigilância Sanitária. Resolução da Diretoria Colegiada RDC $\mathrm{n}^{\circ} 138$, de 8 de fevereiro de 2017 que altera a RDC $\mathrm{n}^{\circ} 7$, de 18 de fevereiro de 2011, que dispõe sobre limites máximos tolerados (LMT) para micotoxinas em alimentos, para alterar os LMT da micotoxina deoxinivalenol (DON) em trigo e produtos de trigo prontos para oferta ao consumidor e os prazos para sua aplicação. Publicada no Diário Oficial da União, n 29 , de 9 de fevereiro de 2017

CONAB (2016) Acompanhamento Safra brasileira Grãos, vol 5- Safra 2015/16- Quinto levantamento, fevereiro 2016. Available at: http://www.conab.gov.br Accessed 06 Sept 2016

Costa RV, Cota LV, Silva DD, Meirelles WF, Lanza FE (2012) Viabilidade técnica e econômica da aplicação de estrobilurinas em milho. Trop Plant Pathol 37:246-254

Duncan KE, Howard JR (2010) Biology of maize kernel infection by Fusarium verticillioides. Mol Plant Microbe Interact 23:6-16

EURL (2006) European Union Reference Laboratories. Commission Regulation No 1881/2006. Available in: http://eur-lex.europa. eu/LexUriServ/LexUriServ.do?uri=CONSLEG:2006R1881 :20100701:EN:PDF. Accessed 29 Dec 2016

FDA (2001) U.S. Food and Drug Administration. Guidance for Industry: Fumonisin Levels in Human Foods and Animal Feeds. Available in: http://www.fda.gov/food/ guidanceregulation/guidancedocuments regulatoryinformation/ucm109231.htm. Accessed 29 Dec 2016

Ferreira DF (2011) Sisvar: a computer statistical analysis system. Cienc Agrotec 35:1039-1042

Gelderblom WCA, Jaskiewicz J, Marasas WFO, Thiel PG, Horak RM, Vleggar R, Kriek NPJ (1988) Fumonisins-micotoxins with cancerpromoting activity produced by Fusarium moliniforme. Appl Environ Microbiol 54:1806-1811

Jackson L, Jablonski J (2004) Fumonisins. In: Magan N, Olsen M (eds) Mycotoxins in food. Wood-head Publishing Ltd. and CRC Press LLC, Cambridge, pp 384-422

Koffi-Nevry R, Koussémon M, Alloue-Boraud WAM, Kouassi K (2013) Assessing the microbiological level and the incidence of watersoaking on the proximate composition of two cultivars of cowpea (Vigna unguiculata L.) grains grown in Côte d'Ivoire. British Microbiol Res J 3:206-217

Lanza FE, Zambolim L, Costa RV, Queiroz VAV, Cota LV, Silva DD, Souza AGC, Figueiredo JEF (2014) Prevalence of fumonisinproducing Fusarium species in Brazilian corn grains. Crop Prot 65:232-237

Machinski M, Valente-Soares LM, Sawazaki E, Bolonhezi D, Castro SL, Bortolleto N (2001) Aflatoxins, ochratoxin a and zearalenone in Brazilian corn cultivars. J Sci Food Agric 81:1001-1007

Munkvold GP, Desjardins AE (1997) Fumonisins in maize. Can we reduce their occurrence? Plant Dis 81:556-565

Oliveira E, Fernandes FT, Casela CR, Pinto NFJA, Ferreira AS (2004) Diagnose e controle de doenças na cultura do milho. In: Galvão JCC, Miranda GV (eds) Tecnologias de produção do milho. Universidade Federal de Viçosa, Viçosa, pp 226-267

Pearson TC, Wicklow DT (2006) Detection of corn kernels infected by fungi. Trans ASABE 49:1235-1245

Picot A, Barreau C, Pinson-Gadais L, Caron D, Lannou C, RichardForget F (2010) Factors of the Fusarium verticillioides - maize 
environment modulating fumonisin production. Crit Rev Microbiol $36: 221-231$

Pinto NFJA (2005) Grãos ardidos em milho. Embrapa Milho e Sorgo: Circular Técnica, Sete Lagoas 66:5

Pinto NFJA, Vargas EA, Preis RA (2007) Qualidade sanitária e produção de fumonisina B1 em grãos de milho na fase de pré-colheita. Summa Phytopathol 33:304-306

Ramos ATM, Moraes MHD, Carvalho RV, Camargo LEA (2010) Levantamento da microflora presente em grãos ardidos e sementes de milho. Summa Phytopathol 36:257-259
Shetty PH, Bhat RV (1999) A physical method for segregation of fumonisin-contaminated maize. Food Chem 66:371-374

Trento SM, Irgang H, Reis EM (2002) Efeito de rotação de culturas, de monocultura e de densidade de plantas na incidência de grãos ardidos em milho. Fitopatol Bras 27:609-613

VICAM (2011) Fumonitest Instruction Manual. Available at: http://vicam.com/fumonisin-test-kits/fumonitest. Accessed 29 March 2016 